\title{
Use of Agave durangensis Bagasse Fibers in the Production of Wood-Based Medium Density Fiberboard (MDF)
}

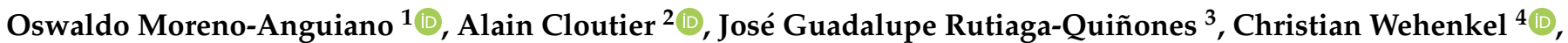 \\ Rigoberto Rosales-Serna ${ }^{5}$, Pamela Rebolledo ${ }^{6}$, Claudia E. Hernández-Pacheco ${ }^{7}$ and Artemio Carrillo-Parra ${ }^{4, *} \mathbb{C}$
}

\section{check for}

updates

Citation: Moreno-Anguiano, O.;

Cloutier, A.; Rutiaga-Quiñones, J.G.; Wehenkel, C.; Rosales-Serna, R.; Rebolledo, P.; Hernández-Pacheco, C.E.; Carrillo-Parra, A. Use of Agave durangensis Bagasse Fibers in the Production of Wood-Based Medium Density Fiberboard (MDF). Forests 2022, 13, 271. https://doi.org/ 10.3390/f13020271

Academic Editor: Arijit Sinha

Received: 12 January 2022

Accepted: 28 January 2022

Published: 8 February 2022

Publisher's Note: MDPI stays neutral with regard to jurisdictional claims in published maps and institutional affiliations.

Copyright: (C) 2022 by the authors. Licensee MDPI, Basel, Switzerland. This article is an open access article distributed under the terms and conditions of the Creative Commons Attribution (CC BY) license (https:// creativecommons.org/licenses/by/ $4.0 /)$.
1 Programa Institucional de Doctorado en Ciencias Agropecuarias y Forestales (PIDCAF), Universidad Juárez del Estado de Durango (UJED), Río Papaloapan y Boulevard Durango, Col. Valle del Sur, Durango 34120, Dgo, Mexico; oswaldo.moreno@ujed.mx

2 Centre de Recherche sur les Matériaux Renouvables (CRMR), Département des Sciences du Bois et de la Forêt, Université Laval, Quebec, QC G1V 0A6, Canada; alain.cloutier@sbf.ulaval.ca

3 Facultad de Ingeniería en Tecnología de la Madera (FITECMA), Universidad Michoacana de San Nicolás de Hidalgo (UMSNH), Avenida Gral. Francisco J. Múgica S/N, Ciudad Universitaria, Morelia, Mich 58040, Mexico; rutiaga@umich.mx

4 Instituto de Silvicultura e Industria de la Madera (ISIMA), Universidad Juárez del Estado de Durango (UJED), Boulevard del Guadiana 501, Ciudad Universitaria, Torre de Investigación, Durango 34120, Dgo, Mexico; wehenkel@ujed.mx

5 Instituto Nacional de Investigaciones Forestales, Agrícolas y Pecuarias (INIFAP), Carretera Durango-El Mezquital km 4.5, Durango 34120, Dgo, Mexico; rosales.rigoberto@inifap.gob.mx

6 Centre d'Innovation des Produits Cellulosiques (INNOFIBRE), Cégep de Trois-Rivières, Trois-Rivières, QC G9A 5E1, Canada; pamela.rebolledo@cegeptr.qc.ca

7 Centro Interdisciplinario de Investigación para el Desarrollo Integral Regional Unidad Durango (CIIDIR), Instituto Politécnico Nacional (IPN), Sigma 119, Fraccionamiento 20 de Noviembre II,

Durango 34120, Dgo, Mexico; chernandezp1801@alumno.ipn.mx

* Correspondence: acarrilloparra@ujed.mx

\begin{abstract}
There is an increasing interest in using non-wood lignocellulosic materials for the production of wood-based medium density fiberboard (MDF). Agave durangensis Gentry bagasse is a waste product produced in large quantities in the mezcal industry. This study evaluated the incorporation of $A$. durangensis bagasse fibers (ADBF) to elaborate MDF wood-based panels. Three types of panels with different ratios (wood fibers: bagasse fibers) were investigated. The ratios evaluated were 100:0, 90:10, and 70:30. The density profiles, water absorption, and thickness swell of the panels were determined, as well as the modulus of elasticity (MOE), modulus of rupture (MOR), and internal bond (IB), according to the ASTM D1037-06a standard. The results were compared to the ANSI A208.2-2016 standard. The effect of the addition of ADBF on the properties of the panels was analyzed. Density profiles were comparable among the three types of panels, while water absorption, thickness swelling, MOE, MOR, and IB were similar between panels with ratios of 100:0 and 90:10. Panels with $10 \%$ and $30 \%$ of ADBF meet the minimum ANSI requirements for quality grade 115 . It is feasible to use up to $30 \%$ of ADBF in the manufacture of wood-based MDF panels.
\end{abstract}

Keywords: non-wood fibers; MOE; MOR; internal bond; thickness swell; water absorption; density

\section{Introduction}

The demand for wood-based panels is increasing rapidly year after year. Fiberboards are among the panels that are increasingly in demand. According to ANSI A208.2-2016, medium density fiberboard (MDF) is recognized as a fiberboard panel of density between 500 and $1000 \mathrm{~kg} \cdot \mathrm{m}^{-3}$ [1]. Medium density fiberboard is a panel composed of cellulosic fibers bonded with resin under heat and pressure. Medium density fiberboards have a wide application for non-structural uses [2], such as in the home and office furniture markets [3]. There are many advantages that distinguish MDF from other panels including edge screwing, painting properties, and good machining [4]. 
Wood is commonly used as raw material for the manufacture of MDF [5]. However, the increasing demand for forest resources for different uses has led to the shortage of wood supply. Therefore, the supply of raw material cannot meet the demand of the wood industry in many regions of the world [6,7]. This is why it is necessary to search for new lignocellulosic materials that may help to fulfill the requirements of the forest products industry [8-10]. These alternative lignocellulosic materials comprise forest harvesting residues such as bark, annual plants, residues from wood products and furniture industries, residues from pulp mills, and recycled paper [6]. However, non-wood fiber has acquired great relevance as a sustainable natural fiber resource for composite products. The use of agricultural fibers as composite panel material is common in many parts of the planet [2] There is interest in agricultural residues, which are generated on a large scale worldwide [9].

In recent years, the use of various non-woody fibers in the production of MDF panels have been studied. Rhododendron [6], canola [11] and wheat straw [5], kenaf [12], oil palm stem [13], coffee bean residues [14], banana leaf stem and lamina [15], okra [8], sugarcane bagasse [4], sunflower and corn stalk [16], and hemp [17] were considered, among others. However, there are still several fibers that have not been used in the production of woodbased MDF, including bagasse from Agave durangensis Gentry.

Agave bagasse is the waste that remains after the boiled agave heads are shredded and ground and the sugars are removed with water. Bagasse fibers could be used to elaborate a broad variety of products such as filters, absorbents, geotextiles, fiberboard, packaging, and molded products [18]. When one liter of mezcal is produced, it generates 15 to $20 \mathrm{~kg}$ of bagasse [19]. In 2019, 178,625 L of mezcal were produced in the state of Durango, Mexico [20]. That year, it is estimated that 2679 to 3572 tons of wet base agave bagasse were produced [21]. The objective of this work was to determine the effect of $A$. durangensis bagasse fibers on the physical and mechanical properties of wood-based MDF panels.

\section{Materials and Methods}

\subsection{Materials}

For this work, A. durangensis bagasse fibers (ADBF) and wood fibers (WF) were used to manufacture the panels. The ADBF was donated by Productora de mezcal Hacienda Dolores located in Durango, Dgo, Mexico. The WF were a mixture of spruce, fir, and pine and were donated by the Uniboard plant company located in Mont-Laurier, Quebec, Canada. The adhesive used was urea formaldehyde (UF) (Table 1) donated by Hexion located in St. Romuald, Quebec, Canada.

Table 1. Properties of urea formaldehyde adhesive.

\begin{tabular}{ccc}
\hline Properties & Unit & Value \\
\hline Appearance & & Clear to white liquid \\
Solids content & $(\%)$ & $67.00 \pm 1.00$ \\
Specific Gravity & $\left(\mathrm{kg} \cdot \mathrm{m}^{-3}\right)$ & $1.305 \pm 0.010$ \\
Viscosity & $\mathrm{CPs}$ & $335 \pm 75$ \\
pH @ $25^{\circ} \mathrm{C}$ & & $8.20 \pm 0.20$ \\
Buffer capacity & $\mathrm{mL}$ & $11.5 \pm 3.0$ \\
Storage life $25^{\circ} \mathrm{C}\left(77^{\circ} \mathrm{F}\right)$ & Days & 21 \\
\hline
\end{tabular}

\subsection{Manufacture of MDF Panels}

The panels were produced at the Composite Panel Laboratory of the Department of Wood and Forest Sciences at Université Laval in Québec, QC, Canada. Three replicates of each panel type were produced for this study (Table 2).

The adhesive and wax were applied to the fiber in a rotary drum blender, using $14 \%$ resin and $1 \%$ wax (by weight of the dry fiber), and $\mathrm{NH}_{4} \mathrm{Cl}$ at $25 \%$ catalyst was added to the resin to lower its $\mathrm{pH}$. Once the furnish was formed, it was taken through a ring refiner (Pallman PSKM8-450) to separate the fiber aggregates formed during blending in the drum. The fiber mat was formed using the refined furnish. It was carried out manually 
using a wooden mold with the dimensions established for the board. The formed mat was pre-pressed before hot pressing. The hot pressing was performed in a Dieffenbacher hot press. The panels had dimensions of 760 by $760 \mathrm{~mm}$, a target thickness of $12 \mathrm{~mm}$, and a target density of $700 \mathrm{~kg} \cdot \mathrm{m}^{-3}$.

Table 2. Types of panels and their ratios of raw material used.

\begin{tabular}{ccc}
\hline & \multicolumn{2}{c}{ Raw Material (\%) } \\
\cline { 2 - 3 } Type of Panel & Wood Fibers (WF) & $\begin{array}{c}\text { A. durangensis Bagasse } \\
\text { Fibers (ADBF) }\end{array}$ \\
\hline MDFC & 100 & 0 \\
MDF10 & 90 & 10 \\
MDF30 & 70 & 30 \\
\hline
\end{tabular}

MDFC: Medium-density fiberboard manufactured with 100\% of WF; MDF10: Medium density fiberboard produced with $90 \%$ of WF and $10 \%$ of ADBF; MDF30: Medium density fiberboard elaborated with $70 \%$ of WF and $30 \%$ of $\mathrm{ADBF}$.

\subsection{Physical and Mechanical Properties of MDF Panels}

The vertical density profile of the manufactured MDF panels was determined using a Quintek X-Ray densimeter (QMS Core Model QPRS-01x and QMS Particleboard Model QDP-01x). The physical and mechanical properties of the panels were determined according to ASTM D1037-06a [22] and ANSI A208.2-2016 [1]. The physical properties evaluated were water absorption and thickness swell at 2 and $24 \mathrm{~h}$, while the mechanical properties determined were internal bond (IB), modulus of elasticity (MOE), and modulus of rupture (MOR). The number of specimens for each test and their characteristics are shown in Table 3. The specimens used for the density profile were the same as those used in the IB tests. The specimens were conditioned for 15 days at $65 \%$ relative humidity and $22{ }^{\circ} \mathrm{C}$. The mechanical tests were carried out in an MTS universal mechanical testing machine with a capacity of $5 \mathrm{kN}$.

Table 3. Tests and samples sizes and number. The samples used for WA2h, WA24h, TS2h, and TS24h tests were the same.

\begin{tabular}{ccccc}
\hline Test & Symbol & Size $(\mathbf{m m})$ & Samples per Panel & Samples per Type of Panel \\
\hline Water absorption after 2 $\mathrm{h}$ & WA2h & & & 12 \\
Water absorption after 24 h & WA2h & $150 \times 150$ & 4 & 18 \\
Thickness swell 2 h & TS2h & & 6 & 18 \\
Thickness swell 24 h & TS24h & $50 \times 50$ & 6 & \\
Internal bond & IB & $75 \times 339$ & & \\
Modulus of elasticity & MOE & & \\
Modulus of rupture & MOR & & & \\
\hline
\end{tabular}

\subsection{Statistical Analysis}

Completely randomized design was used to analyze the data for each variable. Data were analyzed using R Studio software [23]. A Shapiro-Wilk test was used to analyze the normality of data. Analysis of variance (ANOVA) $(p \leq 0.05)$ and comparison of means with Tukey test were performed. Furthermore, Pearson correlation analyses were performed between average density, and water absorption and thickness swell. Additionally, Pearson correlation analyses were performed between internal cohesion and average, maximum, and minimum densities.

\section{Results and Discussion}

\subsection{Panels Density}

The density profiles for the three types of MDF panels are presented in Figure 1. It shows a higher density near the surfaces, while the center of the panels presented a decrease 
in density. According to Halvarsson et al. [24], in MDF panels with this type of density profile, it is the more compressed fibers of the high-density surface layers that expand the most when the MDF samples are immersed in water for $24 \mathrm{~h}$, thus causing swelling. The panels with 10 and 30\% of ADBF presented a similar density profile to the WF panel (Figure 1A). However, there is a minimal difference between the profiles, which may be caused by the ADBF; therefore, it is likely that this small difference influences the properties of these panels. The density profile is related to the performance of the panel. A deep density profile allows the board to better laminate, glue, and finish due to the high density of the surface [25]. On the other hand, when the density profile is more flat, it can reduce the bending properties of the panels [26].
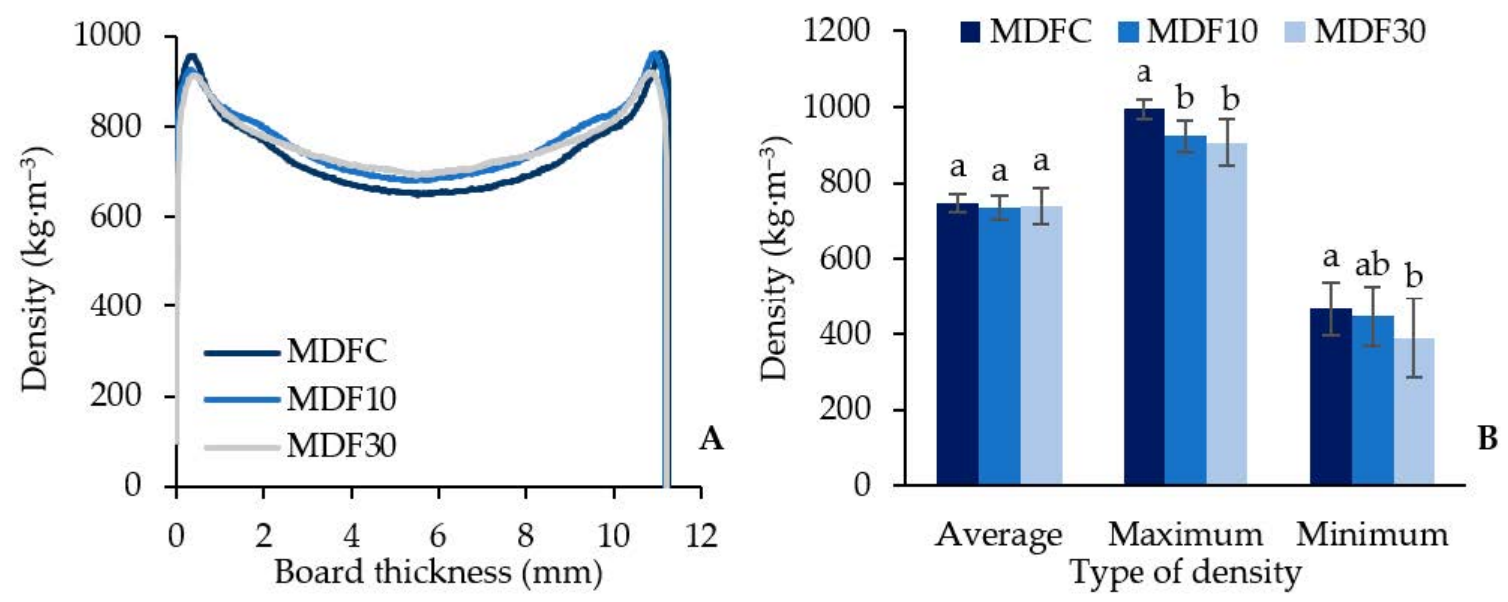

Figure 1. Density of MDF panels. (A) Density profiles of the average of eight samples of MDF panels. (B) Types of density of the panels obtained from the X-ray densitometry. Different lowercase letters represent statistically significant difference among panels by Tukey test $(p \leq 0.05)$.

The highest average density was obtained for MDFC $\left(749 \mathrm{~kg} \cdot \mathrm{m}^{-3}\right)$, followed by MDF30 $\left(738 \mathrm{~kg} \cdot \mathrm{m}^{-3}\right)$ and MDF10 $\left(735 \mathrm{~kg} \cdot \mathrm{m}^{-3}\right)$. The higher maximum density was obtained by MDFC $\left(995 \mathrm{~kg} \cdot \mathrm{m}^{-3}\right)$, while the minimum density was obtained for MDF30 $\left(390 \mathrm{~kg} \cdot \mathrm{m}^{-3}\right)$. There are no statistically significant differences between the three types of panels in the average, but there are for the maximum density, with MDFC being different from MDF10 and MDF30, while for the minimum density, MDFC showed a significant difference with MDF30 (Figure 1B). The $p$ value of the ANOVA test for average, maximum, and minimum density of the panels is shown in Table 4. Panels did not present statistically significant difference in average density, while in maximum and minimum densities, there was significant difference.

Table 4. $p$ value of ANOVA test for average, maximum, and minimum density of the panels.

\begin{tabular}{cc}
\hline Type of Density & $p$ Value \\
\hline Average & 0.4565 \\
Maximum & $3.08 \times 10^{-7 *}$ \\
Minimum & $0.0268^{*}$ \\
\hline
\end{tabular}

* Statistically significant difference for $p \leq 0.05$.

\subsection{Water Absorption and Thickness Swell}

Water absorption and thickness swelling after 2 and $24 \mathrm{~h}$ in water immersion are shown in Figure 2. The lowest water absorption (Figure 2A) at 2 and $24 \mathrm{~h}$ was obtained for MDFC (3.7\% and 18.9\%, respectively), while MDF30 had the highest absorption at $2(4.7 \%)$ and $24 \mathrm{~h}(22.4 \%)$. There were no significant differences between MDFC and MDF10 in water absorption at 2 and $24 \mathrm{~h}$; however, there were significant differences between these and MDF30. The lowest thickness swelling (Figure 2B) was presented by MDFC at both 
$2(0.9 \%)$ and $24 \mathrm{~h}(4.5 \%)$, followed by MDF10 (1.1\% and $4.9 \%$, respectively). There were no statistically significant differences between MDF10 and the other panels for thickness swell at $2 \mathrm{~h}$, but there was between MDFC and MDF30. Statistically significant differences were found between the three types of panels in thickness swell at $24 \mathrm{~h}$.
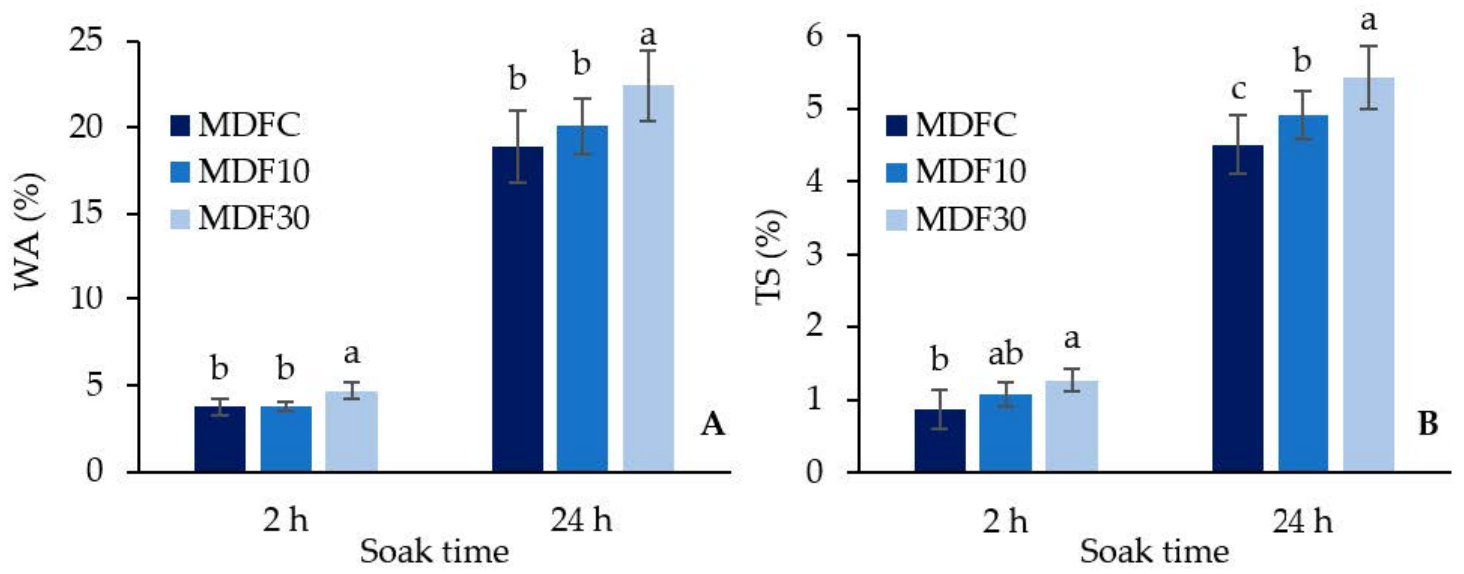

Figure 2. Dimensional stability. (A) Water absorption after 2 and $24 \mathrm{~h}$ of submersion of MDF panels. (B) Thickness swelling after 2 and $24 \mathrm{~h}$ of submersion of MDF panels. Different lowercase letters represent statistically significant difference among panels by Tukey test $(p \leq 0.05)$.

Table 5 shows the $p$ value of ANOVA test for WA and TS after 2 and $24 \mathrm{~h}$ in water immersion of the panels. The panels presented statistically significant difference in WA and TS, both at 2 and $24 \mathrm{~h}$.

Table 5. $p$ value of ANOVA for WA and TS at 2 and $24 \mathrm{~h}$ of submersion of the panels.

\begin{tabular}{cc}
\hline Property & $p$ Value \\
\hline WA2h & $1.29 \times 10^{-6 *}$ \\
WA24h & $0.000269 *$ \\
TS2h & $0.000162 *$ \\
TS24h & $1.05 \times 10^{-5 *}$ \\
\hline
\end{tabular}

*Statistically significant difference for $p \leq 0.05$.

The results indicate that ADBF decreases the resistance of the panels to water absorption and swelling in thickness. According to Moreno-Anguiano et al. [21], fiber of bagasse of $A$. durangensis contains $32.4 \%$ extractives, $44.7 \%$ holocellulose, $7.6 \%$ lignin, and $12.6 \%$ ash. Thus, the high content of extractives present in ADBF could have caused poor gluing of these fibers, due to the migration of extractives to the surface after high pressing temperatures [27]. On the other hand, Xing et al. [10] stated that excessive curing of the UF resin in the surface layers of the panel may also have caused high thickness swelling. In addition, agricultural residues have a higher buffer capacity compared to wood [28]. These aspects remain to be investigated further.

Water absorption is a property of panels related to their dimensional stability, which has been studied by several authors. Despite water absorption is reported in the literature, it is not a characteristic evaluated in the ANSI A208.2-2016 standard. The results obtained for WA in MDF10 and MDF30 panels are lower than those reported by Akgül [29] for MDF made with 10-90\%, and 30-70\% of Urtica dioica L. stem-wood fiber, respectively. Akgül [29] indicates that the addition of Urtica dioica stem fiber to the panels reduced their physical properties; nonetheless, they still met the standards. Similarly, MDF30 showed lower WA than those obtained by Akgül and Tozluoğlu [30] on MDF from Arachis hypogaea L. husk and wood fibers. These authors report that Arachis hypogea husk could be added up to 30\% for the production of MDF.

The TS values obtained are lower than those reported by other authors for panels made from wood and non-wood fiber [31-33]. Lee et al. [31] evaluated MDF manufactured 
from blends of sugar cane bagasse and tallow tree fibers. They found that the maximum percentage to manufacture MDF is $50 \%$ without impact on thickness swelling. Whereas Akgül et al. [32] produced MDF with mixtures of pine wood and corn stalks, and they mentioned that the addition of corn stalks reduced the panel properties.

The TS (expressed in $\mathrm{mm}$ ) at 2 and $24 \mathrm{~h}$ of immersion is plotted as a function of average density in Figure 3. The TS values presented by the panels meets the maximum required by ANSI A208.2-2016 for medium density fiberboard.
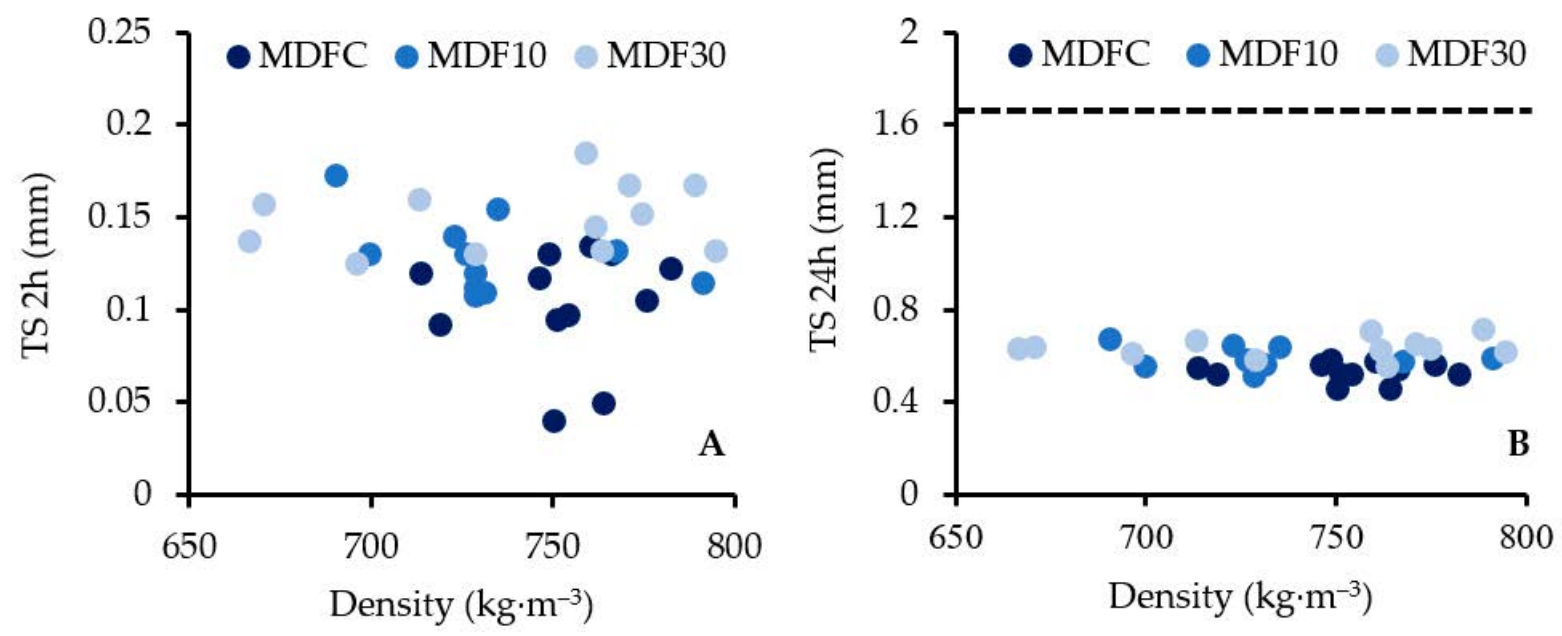

Figure 3. Thickness swell as function of density of MDF panels. (A) Thickness swell after $2 \mathrm{~h}$ as a function of density of MDF panels. (B) Thickness swell after $24 \mathrm{~h}$ as a function of density of MDF panels. The dotted line represents the maximum TS for panels $<15 \mathrm{~mm}$ according to ANSI A208.2-2016.

The Pearson correlation among average density values and water absorption and thickness swelling is presented in Table 6. There is a significant correlation between the average density of MDF30 and water absorption after $24 \mathrm{~h}$, which is a strong positive correlation. On the other hand, there is no significant correlation between the rest of the variables.

Table 6. Pearson correlation for average density values and water absorption and thickness swelling of MDF panels.

\begin{tabular}{clcccc}
\hline & & WA2h & WA24h & TS2h & TS24h \\
\hline \multirow{2}{*}{ MDFC } & Correlation & -0.3007 & -0.1049 & 0.2098 & 0.1049 \\
& Significance & 0.34 & 0.75 & 0.51 & 0.75 \\
\multirow{2}{*}{ MDF10 } & Correlation & -0.0403 & 0.2134 & -0.4775 & -0.312 \\
& Significance & 0.90 & 0.51 & 0.12 & 0.32 \\
\multirow{2}{*}{ MDF30 } & Correlation & 0.5412 & $0.6124 *$ & 0.3434 & 0.3272 \\
& Significance & 0.07 & 0.03 & 0.27 & 0.30 \\
\hline *
\end{tabular}

* Significant correlation $(p \leq 0.05)$.

\subsection{Internal Bond}

Internal bond was higher in $\operatorname{MDFC}\left(0.84 \mathrm{~N} \cdot \mathrm{mm}^{-2}\right)$, while the lowest resistance was presented by MDF30 $\left(0.70 \mathrm{~N} \cdot \mathrm{mm}^{-2}\right)$. MDF10 had an internal bond of $0.83 \mathrm{~N} \cdot \mathrm{mm}^{-2}$. There are no statistically significant differences between MDF10 and MDFC; similarly, there are no significant differences between MDFC and MDF30. The presence of $10 \%$ ADBF does not affect the internal bonding strength with respect to MDFC panels; however, increasing the percentage of ADBF to 30 decreases. The internal bonding strength showed by the panels with ADBF meets the minimum required by ANSI A208.2-2016. The MDF10 panels reach grade 155 while MDF30 meets grade 130 (Figure 4).

The results obtained for IB are higher than those reported by other authors for panels with similar proportions of wood fiber and non-wood fiber. Gillah et al. [34] reported an 
IB of $0.48 \mathrm{~N} \cdot \mathrm{mm}^{-2}$ for sisal and wood fiber panels, in which their IB was reduced with the addition of sisal fibers. Abdul et al. [35] indicated an IB of $0.73 \mathrm{~N} \cdot \mathrm{mm}^{-2}$ for oil palm empty fruit bunch and rubber wood panels. They also reported that the increase of nonwood fibers into the panels decreased their properties. On the other hand, Belini et al. [36] obtained an IB of $0.58 \mathrm{~N} \cdot \mathrm{mm}^{-2}$ for eucalyptus and bagasse fiber panels with a ratio of $75: 25 \%$. Nevertheless, the IB increased to $0.80 \mathrm{~N} \cdot \mathrm{mm}^{-2}$ when a ratio of $50: 50 \%$ was used.
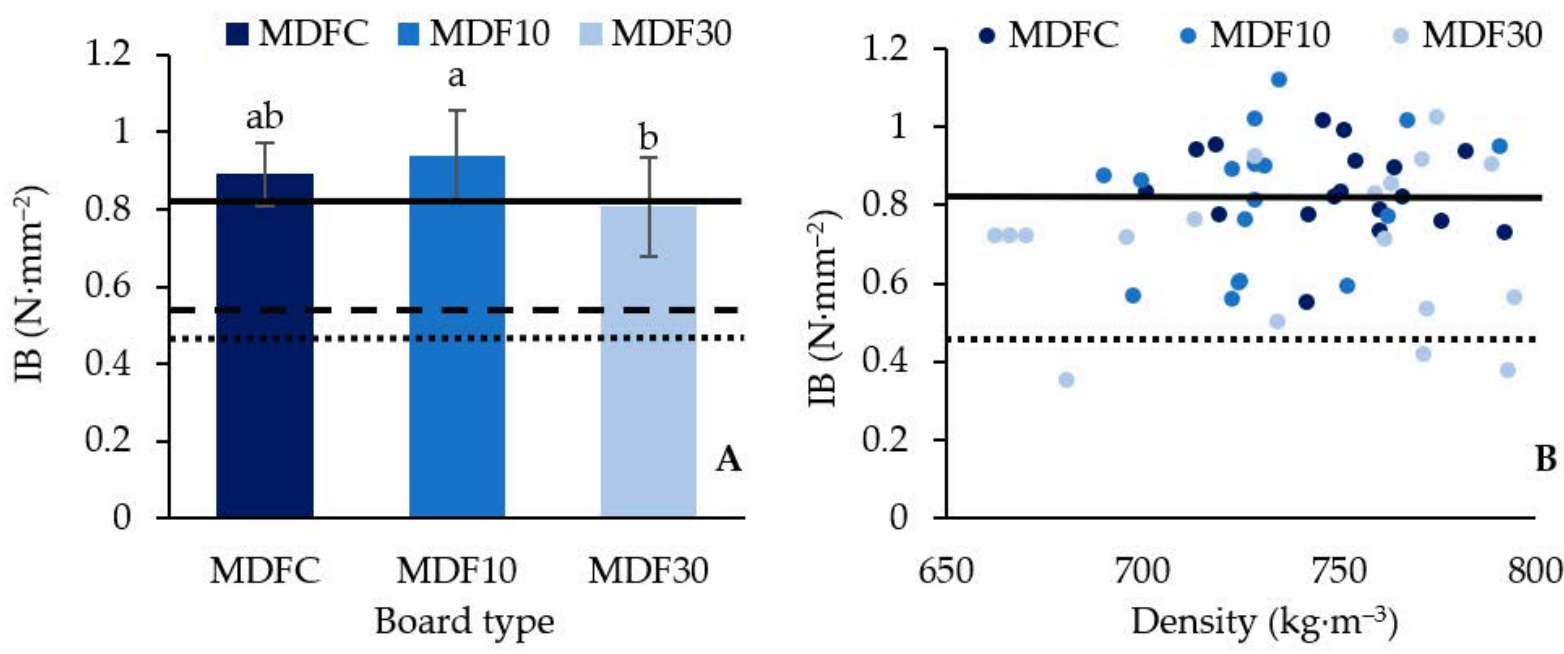

\section{ANSI-115 - - ANSI-130 - ANSI-155}

Figure 4. Internal bond of MDF panels (A) Internal bond of MDF panels. Different lowercase letters represent statistically significant difference among panels by Tukey test $(p \leq 0.05)$. $p$ value of ANOVA for internal bond is 0.0195. (B) Internal bond as a function of density of MDF panels. Lines represent MDF standard requirement for 115, 130, and 155 grades according to ANSI A208.2-2016.

The decrease of IB in MDF30 panels may be caused by the high presence of extractives in bagasse fibers. Regularly, extractives modify the properties of lignocellulosic materials, which, in turn, alters their adhesion properties [37]. It is possible that the waxes in the bagasse fibers are incompatible with phenolic resins because of their different polarities. Thus, the adhesive decreases its ability to penetrate the lignocellulosic material, resulting in a lower resistance to internal bond of the panels [38].

Table 7 shows the Pearson correlation between internal bond and the different densities obtained in the X-ray densitometer. Neither of the MDF panels presented significant correlations between internal cohesion and average, maximum and minimum density.

Table 7. Pearson correlation for different density values and internal bond of MDF panels.

\begin{tabular}{clccc}
\hline Test & & Average Density & Maximum Density & Minimum Density \\
\hline \multirow{2}{*}{ MDFC } & Correlation & -0.149 & 0.027 & 0.181 \\
& Significance & 0.56 & 0.91 & 0.47 \\
\multirow{2}{*}{ MDF10 } & Correlation & 0.425 & 0.290 & 0.286 \\
& Significance & 0.08 & 0.24 & 0.25 \\
\multirow{2}{*}{ MDF30 } & Correlation & -0.005 & 0.147 & 0.234 \\
& Significance & 0.98 & 0.56 & 0.35 \\
\hline
\end{tabular}

Significant correlation $(p \leq 0.05)$.

\subsection{Modulus of Elasticity (MOE) and Modulus of Rupture (MOR)}

Figure 5 shows the values of the modulus of elasticity and modulus of rupture obtained for each type of board. MDFC panels presented the highest MOE $\left(1955 \mathrm{~N} \cdot \mathrm{mm}^{-2}\right)$; nevertheless, there is no significant difference between them and MDF10 $\left(1786 \mathrm{~N} \cdot \mathrm{mm}^{-2}\right)$. On the other hand, MDF30 panels had the lowest MOE $\left(1526 \mathrm{~N} \cdot \mathrm{mm}^{-2}\right)$, which was signif- 
icantly different from MDFC and MDF10 (Figure 5A). Regarding the MOR, the highest average value was shown by MDFC $\left(17.8 \mathrm{~N} \cdot \mathrm{mm}^{-2}\right)$, followed by MDF10 $\left(17.6 \mathrm{~N} \cdot \mathrm{mm}^{-2}\right)$; however, there were no significant differences between them. On the other hand, MDF30 panels obtained the lowest value $\left(13.2 \mathrm{~N} \cdot \mathrm{mm}^{-2}\right)$ and were significantly different from MDFC and MDF10 (Figure 5B). The MOE and MOR values are lower than those reported by other authors for processed wood fiber and non-wood fibers MDF panels using fiber ratios similar to this work. Çöpür et al. [39] report MOE of 2320 and $2852 \mathrm{~N} \cdot \mathrm{mm}^{-2}$ and MOR of $18.6 \mathrm{~N} \cdot \mathrm{mm}^{-2}$ for panels made from hazelnut shells and fibers of Pinus nigra and Fagus orientalis. They stated that up to $20 \%$ of hazelnut shells could be utilized to manufacture panels which meet the standards. Akgül et al. [40] indicate MOE of $4035 \mathrm{~N} \cdot \mathrm{mm}^{-2}$ and MOR of $27.1 \mathrm{~N} \cdot \mathrm{mm}^{-2}$ in corn stalk and oak wood panels. In their case, the incorporation of corn stalk did not increase the MOE and MOR of the panels. Although the MOE and MOR of the present work were lower than other reported, MDF10 and MDF30 panels met the minimum value required by ANSI A208.2-2016 in MOE and MOR for grade 115 panels.
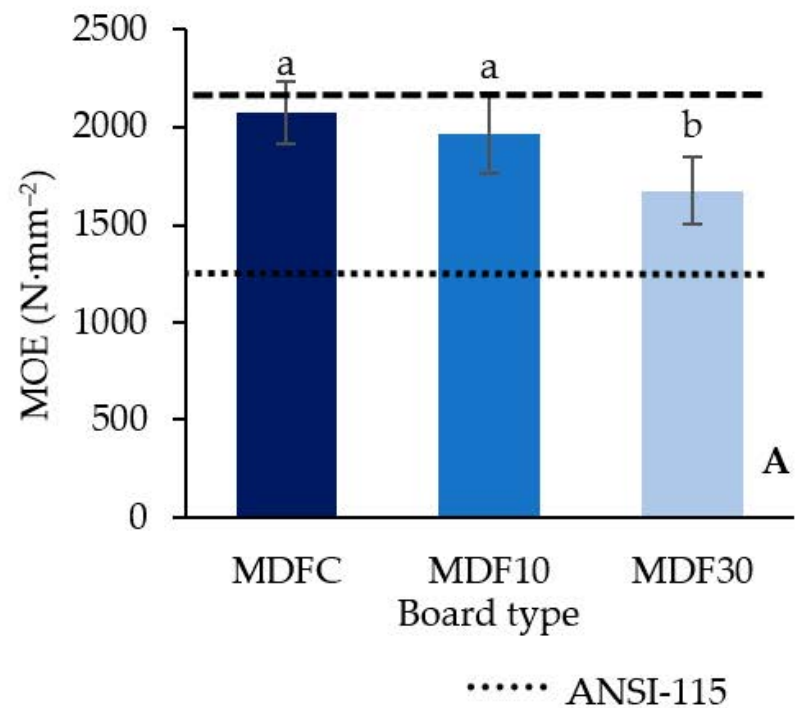

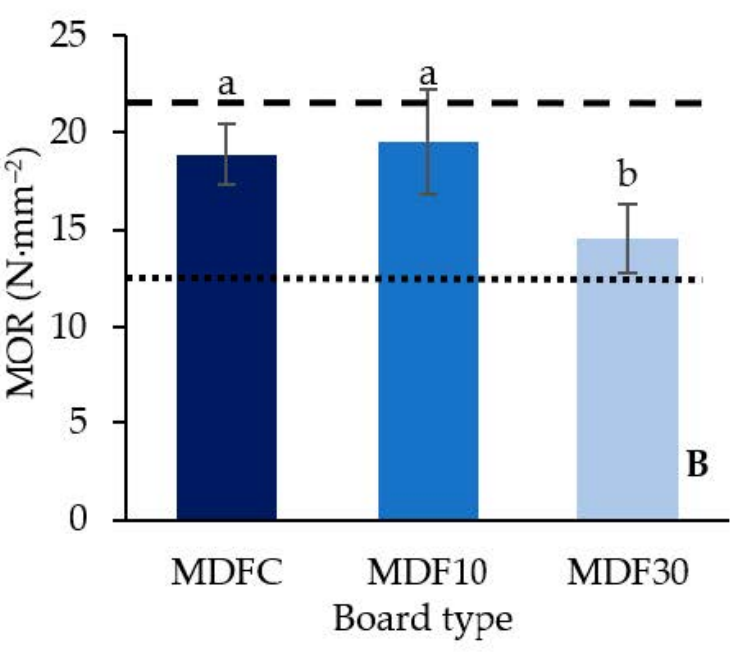

- - ANSI-130

Figure 5. (A) Modulus of elasticity of MDF panels. $p$ value of ANOVA for modulus of elasticity is $9.84 \times 10^{-5}$. (B) Modulus of rupture of MDF panels. $p$ value of ANOVA for modulus of rupture is $6.50 \times 10^{-6}$. Different lowercase letters represent statistically significant difference among panels by Tukey test $(p \leq 0.05)$. Dotted lines represent MDF standard requirement for 115 and 130 grades according to ANSI A208.2-2016.

The decrease in mechanical properties of MDF30 panels may be due to the presence of small particles in the ADBF and the minimal contact between them [33]. The $\mathrm{pH}$ of the $\mathrm{ADBF}$ is another factor that could reduce the mechanical strength of the panels. Moreno et al. [21] report that $A$. durangensis bagasse fiber has a $\mathrm{pH}$ of 5.8. According to Baharoglu et al. [41], materials with low $\mathrm{pH}$ result in panels with low strength properties, because adhesive curing occurs before hot pressing when the $\mathrm{pH}$ of the fibers is low [42]. When fibers with lower $\mathrm{pH}$ and UF resin are used in the MDF industry, it is expected to result in a higher degree of pre-curing during drying [43]. Nevertheless, UF is an adhesive that cures better in an acidic environment [44]. The aforementioned is in agreement with the results obtained by Park et al. [45], who reported that high alkalinity fibers retarded the curing of UF in MDF. According to Stefke and Dunky [46], the condensation reactions of UF resin take place during the hardening process causing a cross-linked condition and thus developing the internal bond between the fibers. UF preferably needs a low $\mathrm{pH}$ for the above to take place. 


\section{Conclusions}

The results show that the incorporation of $A$. durangensis bagasse fiber does not affect the physical and mechanical properties of wood-based MDF panels. The MDF panels made with $10 \%$ of ADBF did not present significant differences in their physical and mechanical properties with the wood-based panels, except for the thickness swelling after $24 \mathrm{~h}$. In contrast, panels with 30\% ADBF showed significant differences from wood fiber panels. However, both panels with $10 \%$ and $30 \%$ of ADBF meet the requirements of grade 115 for medium density fiberboard for interior applications according to the American National Standard. Density did not correlate concerning water absorption and thickness swelling, except for the MDF30 board after $24 \mathrm{~h}$. The densities did not present correlation with internal bonding. The addition of ADBF to panels did not affect the type of density profile of panels; however, the ADBF reduced the density of the MDF panels. These findings demonstrate the potential of $A$. durangensis bagasse fiber to be used as a complement in the manufacture of wood-based MDF panels.

Author Contributions: Conceptualization, A.C.-P. and O.M.-A.; methodology, A.C.-P., O.M.-A., A.C. and P.R.; software, O.M.-A. and C.W.; validation, A.C.-P., O.M.-A. and J.G.R.-Q.; formal analysis, A.C.-P., O.M.-A., R.R.-S. and J.G.R.-Q.; investigation, O.M.-A. and A.C.; resources, A.C., R.R.-S. and C.E.H.-P.; writing - original draft preparation, O.M.-A.; writing-review and editing, A.C.-P., A.C., P.R., J.G.R.-Q., C.W. and C.E.H.-P. All authors have read and agreed to the published version of the manuscript.

Funding: This research received no external funding.

Data Availability Statement: The data presented in this study are available on request from the first author.

Acknowledgments: The authors thank the Centre de Recherche sur les Matériaux Renouvables of Université Laval for the support and facilities granted to carry out this work. The authors also thank the Programa Institucional de Doctorado en Ciencias Agropecuarias y Forestales (PIDCAF) for its support. Finally, the authors express their gratitude to CONACYT for the doctoral scholarship awarded to Oswaldo Moreno-Anguiano.

Conflicts of Interest: The authors declare no conflict of interest.

\section{References}

1. ANSI A208.2. Medium Density Fiberboard (MDF) for Interior Applications; American National Standard Institute: Gaithersburg, MD, USA, 2016.

2. Indrayani, Y.; Setyawati, D.; Yoshimura, T.; Umemura, K. Termite resistance of medium density fibreboard produced from renewable biomass of agricultural fibre. Procedia Environ. Sci. 2014, 20, 767-771. [CrossRef]

3. Taghiyari, H.R.; Majidi, R.; Arsalan, M.G.; Moradiyan, A.; Militz, H.; Ntalos, G.; Papadopoulos, A.N. Penetration of different liquids in wood-based composites: The effect of adsorption energy. Forests 2021, 12, 63. [CrossRef]

4. Abdellah, M.Y.; Fahmy, H.S.; Abdel-Jaber, G.T.; Hashem, A.M. Characteristic properties of glass fiber reinforced sugarcane bagasse medium density fiber board. Ciênc. Tecnol. Mater. 2017, 29, 97-105. [CrossRef]

5. Halvarsson, S.; Edlund, H.; Norgren, M. Manufacture of non-resin wheat straw fiberboards. Ind. Crop. Prod. 2009, 29, 437-445. [CrossRef]

6. Akgül, M.; Çamlibel, O. Manufacture of medium density fiberboard (MDF) panels from rhododendron (R. ponticum L.) biomass. Build. Environ. 2008, 43, 438-443. [CrossRef]

7. Taghiyari, H.R.; Mohammad-Panah, B.; Morrel, J.J. Effects of wollastonite on the properties of medium-density fiberboard (MDF) made from wood fibers and camel-thorn. Maderas. Cienc. Tecnol. 2016, 18, 157-166. [CrossRef]

8. Akgül, M.; Uner, B.; Çamlibel, O.; Ayata, U. Manufacture of medium density fiberboard (MDF) panels from agribased lignocellulosic biomass. J. Wood Sci. 2017, 62, 615-624.

9. Silva, D.W.; Scatolino, M.V.; do Prado, N.R.T.; Mendes, R.F.; Mendes, L.M. Addition of different proportions of castor husk and pine wood in particleboards. Waste Biomass Valor. 2018, 9, 139-145. [CrossRef]

10. Xing, C.; Deng, J.; Zhang, S.Y.; Riedl, B.; Cloutier, A. Impact of bark content on the properties of medium density fiberboard (MDF) in four species grown in eastern Canada. For. Prod. J. 2006, 56, 64-69.

11. Yousefi, H. Canola straw as a bio-waste resource for medium density fiberboard (MDF) manufacture. Waste Manag. 2009, 29, 2644-2648. [CrossRef] 
12. Aisyah, H.A.; Paridah, M.T.; Sahri, M.H.; Anwar, U.M.K.; Astimar, A.A. Properties of medium density fibreboard (MDF) from kenaf (Hibiscus cannabinus L.) core as function of refining conditions. Compos. B Eng. 2013, 44, 592-596. [CrossRef]

13. Ibrahim, Z.; Aziz, A.A.; Ramli, R.; Mokhtar, A.; Lee, S. Effect of refining parameters on medium density fibreboard (MDF) properties from oil palm trunk (Elaeis guineensis). Open J. Compos. Mater. 2013, 3, 127-131. [CrossRef]

14. Yang, I.; Lee, K.; Oh, S. Manufacture and performance evaluation of medium-density fiberboard made with coffee bean residuewood fiber. J. Korean Wood Sci. Technol. 2013, 41, 293-301. [CrossRef]

15. Rashid, M.M.; Das, A.K.; Shams, M.I.; Biswas, S.K. Physical and mechanical properties of medium density fiber board (MDF) fabricated from banana plant (Musa sapientum) stem and midrib. J. Indian Acad. Wood Sci. 2014, 11, 1-4. [CrossRef]

16. Ashori, A.; Nourbakhsh, A. Bio-based composites from waste agricultural residues. Waste Manag. 2010, 30, 680-684. [CrossRef]

17. Mihailova, J.; Savov, V.; Grigorov, R. Utilization of mass of industrial hemp in the production of medium-density fibreboards (MDF). J. Anatol. Environ. Anim. Sci. 2019, 4, 679-684. [CrossRef]

18. Iñiguez-Covarrubias, G.; Lange, S.E.; Rowell, R.M. Utilization of byproducts from the tequila industry: Part 1: Agave bagasse as a raw material for animal feeding and fiberboard production. Bioresour. Technol. 2001, 77, 25-32. [CrossRef]

19. Ilangovan, K.; Linerio, J.; Álvarez, E.; Briones, M.; Noyola, A. Anaerobic treatment of tequila vinasse. In Environmental Biotechnology and Cleaner Bioprocesses; Olguin, E.J., Sanchez, G., Hernandez, E., Eds.; Taylor \& Francis: London, UK, 2010; pp 101-106.

20. CRM. Informe Estadístico 2020. Available online: http://www.crm.org.mx/PDF/INF_ACTIVIDADES/INFORME2019.pdf (accessed on 10 September 2020).

21. Moreno-Anguiano, O.; Carrilo-Parra, A.; Rutiaga-Quiñones, J.G.; Wehenkel, C.; Pompa-García, M.; Márquez-Montesino, F.; Pintor-Ibarra, L.F. Chemical composition of Luffa aegyptiaca Mill., Agave durangensis Gentry and Pennisetum sp. PeerJ 2021, 9, e10626. [CrossRef]

22. ASTM D1037. Standard Test Methods for Evaluating Properties of Wood-Based Fiber and Particle Panel Materials; American Society for Testing and Materials: West Conshohocken, PA, USA, 2006.

23. R Core Team. R: A Language and Environment for Statistical Computing; R Foundation for Statistical Computing: Vienna, Austria, 2020.

24. Halvarsson, S.; Edlund, H.; Norgren, M. Wheat straw as raw material for manufacture of medium density fiberboard (MDF). Bioresources 2010, 5, 1215-1231.

25. Wang, S.; Winistorfer, P.M.; Young, T.M.; Helton, C. Step-closing pressing of medium density fiberboard; Part 1 . Influences on the vertical density profiles. Holz Roh Werkst. 2001, 59, 19-26. [CrossRef]

26. Shi, J.L.; Zhang, S.Y.; Riedl, B.; Brunette, G. Flexural properties, internal bond strength, and dimensional stability of medium density fiberboard panels made from hybrid poplar clones. Wood Fiber Sci. 2005, 37, 629-637.

27. Faria, D.L.; Scatolino, M.V.; Lopes, T.A.; Júnior, L.M.; Mota, G.S.; Júnior, J.B.G.; Mendes, L.M.; Soriano, J. Performance of glulam beams produced with free-formaldehyde adhesive and underexploited rubber wood treated with preservatives solutions of chromated copper borate and pyrethroids. J. Adhes. Sci. Technol. 2019, 112, 1145-1162. [CrossRef]

28. Hosseinkhani, H.; Euring, M.; Kharazipour, A. Utilization of date palm (Phoenix dactylifera L.) pruning residues as raw material for MDF manufacturing. J. Mater. Sci. Res. 2015, 4, 46. [CrossRef]

29. Akgül, M. Suitability of stinging nettle (Urtica dioica L.) stalks for medium density fiberboards production. Compos. B Eng. 2013, 45, 925-929. [CrossRef]

30. Akgül, M.; Tozluoğlu, A. Utilizing peanut husk (Arachis hypogaea L.) in the manufacture of medium-density fiberboards. Bioresour. Technol. 2008, 99, 5590-5594. [CrossRef] [PubMed]

31. Lee, S.; Shupe, T.F.; Hse, C. Utilization of Chinese tallow tree and bagasse for medium density fiberboard. For. Prod. J. 2004, 54, $71-76$.

32. Akgül, M.; Güler, C.; Çöpür, Y. Certain physical and mechanical properties of medium density fiberboards manufactured from blends of corn (Zea mays indurata Sturt.) stalks and pine (Pinus nigra) wood. Turk. J. Agric. For. 2010, 34, 197-206. [CrossRef]

33. Akgül, M.; Korkut, S.; Çamlibel, O.; Ayata, Ü. Some chemical properties of Luffa and its suitability for medium density fiberboard (MDF) production. Bioresources 2013, 8, 1709-1717. [CrossRef]

34. Gilla, P.R.; Irle, M.A.; Amartey, S.A. Development and production of laboratory scale novel MDF panels from composite and nonwoven mattresses of sisal and wood fibre mixtures. Holz Roh Werkst. 2000, 58, 324-330. [CrossRef]

35. Abdul Khalil, H.P.S.; Nur Firdaus, M.Y.; Jawaid, M.; Anis, M.; Ridzuan, R.; Mohamed, A.R. Development and material properties of new hybrid medium density fibreboard from empty fruit bunch and rubberwood. Mater. Des. 2010, 31, 4229-4236. [CrossRef]

36. Belini, U.G.; Filho, M.T.; Louzada, J.L.P.C.; Rodrigues, J.C.C.; Astolphi, J.R.S. Pilot study for MDF manufacture from sugarcane bagasse and eucalyptus fibers. Eur. J. Wood Wood Prod. 2012, 70, 537-539. [CrossRef]

37. Gadhave, R.V.; Mahanwar, P.A.; Gadekar, P.T. Factor affecting gel time/process-ability of urea formaldehyde resin based wood adhesives. Open J. Polym. Chem. 2017, 7, 33-42. [CrossRef]

38. Hse, C.Y.; Kuo, M.I. Influence of extractives on wood gluing and finishing-A review. For. Prod. J. 1998, 38, 52-56.

39. Çöpür, Y.; Güler, C.; Taşçioğlu, C.; Tozluoğlu, A. Incorporation of hazelnut shell and husk in MDF production. Bioresour. Technol. 2008, 99, 7402-7406. [CrossRef]

40. Akgül, M.; Güler, C.; Üner, B. Opportunities in utilization of agricultural residues in bio-composite production: Corn stalk (Zea mays indurata Sturt) and oak wood (Quercus Robur L.) fiber in medium density fiberboard. Afr. J. Biotechnol. 2010, 9, 5090-5098. 
41. Baharoglu, M.; Nemli, G.; Sarı, B.; Birtürk, T.; Bardak, S. Effects of anatomical and chemical properties of wood on the quality of particleboard. Compos. B Eng. 2013, 52, 282-285. [CrossRef]

42. Nemli, G.; Yıldız, S.; Gezer, E.D. The potential for using the needle litter of Scotch pine (Pinus sylvestris L.) as a raw material for particleboard manufacturing. Bioresour. Technol. 2008, 99, 6054-6058. [CrossRef] [PubMed]

43. Xing, C.; Zhang, S.Y.; Deng, J.; Riedl, B.; Cloutier, A. Medium-density fiberboard performance as affected by wood fiber acidity, bulk density, and size distribution. Wood Sci. Technol. 2006, 40, 637-646. [CrossRef]

44. Poblete, H.; Burgos, R. Eucalyptus nitens como materia prima para tableros de partículas. Maderas. Cienc. Tecnol. 2010, 12, 25-35. [CrossRef]

45. Park, B.D.; Kim, Y.S.; Riedl, B. Effect of wood-fiber characteristics on medium density fiberboard (MDF) performance. Korean Wood Sci. Technol. 2001, 29, 27-35.

46. Stefke, B.; Dunky, M. Catalytic influence of wood on the hardening behavior of formaldehyde-based resin adhesives used for wood-based panels. J. Adhes. Sci. Technol. 2006, 20, 761-785. [CrossRef] 